\title{
Assessment of Heavy Metal Pollution in Soil and Barley Crop Grown Around Mugher Cement Factory, Ethiopia
}

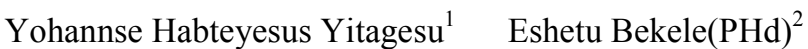 \\ 1.Ethiopia Institute of Agricultural Research,Holetta Research Center, Holetta, Ethiopia \\ 2. Department of Applied chemistry, Adama Science and Technology university
}

\begin{abstract}
Different researches showed that cement manufacturing is one of the significant sources of heavy metal pollution in soil through precipitation and fallout. In this study, heavy metals pollution in soil and barley crop grown around Mugher cement factory were investigated. A total of 36 soil samples at different distance from the factory $(0-500 \mathrm{~m}, 500-1500 \mathrm{~m}$ and $4000 \mathrm{~m})$ and 22 barley sample were collected and analyzed at Holetta Agricultural Chemistry Laboratory. The parameters analyzed in soil sample includes: Available heavy metals, total heavy metals and major physico-chemical properties. Dry ashing method was used to determine the level of heavy metals in barley sample. Analysis for the concentration of heavy metals were conducted using Atomic Absorption Spectrometer. One-way ANOVA were used to compare the mean values between experimental treatments with SPSS statistical software. The Geo-accumulation Index and transfer factor of each heavy metal were computed and interpreted. The Igeo values are below zero indicates that the soil quality is practically unpolluted. The results in soil physico-chemical properties showed that neutral to moderately alkaline soil $\mathrm{pH}$, clay to clay loam soil texture, medium to high category of phosphorus, nitrogen, and potassium. The cement dust therefore effluence to enhance the $\mathrm{pH}$ level to the alkaline, as a result the contents of major soil physicochemical properties declines near to the factory. The values of heavy metals transfer factors from soil to barley crop are below one indicates that the crop have not influenced by heavy metals that uptaked from cement dust polluted fields. The levels of heavy metals determined in the analyzed barley samples also found to be below the permissible limit set by FAO/WHO; hence, the concentration of these heavy metals in the barley crop analyzed, may not presently pose a health hazard and can as well serve as sources of essential trace metals to the population.
\end{abstract}

Keywords: Heavy metals, Atomic Absorption Spectrometer, pollution indices, transfer factor DOI: $10.7176 / \mathrm{JNSR} / 9-1-02$

\section{Introduction}

Environmental pollution related to urbanization and industrialization is inevitable unless proper measures are taken. Air pollution is one of the serious problems in recent times as a result of rapid increase in number of vehicles, cement factories, steel and coal industries and petrochemical industries coupled with deforestation of natural forest. In comparison to the effect of gaseous pollutants on the air quality, little attention is given to the effect of particulate pollutants on soil and vegetation properties $[1,2]$.

Heavy metals enter the surroundings by natural means and through human activities. It is projected that the anthropogenic emission into the atmosphere is one-to-three orders of magnitude higher than natural fluxes [3]. The emission of anthropogenic heavy metal compounds causes considerable changes in biogeochemical cycles of some elements. Increasing industrialization and urbanization had anthropogenic contribution of heavy metals in biosphere and had largest availability in soil and to a relatively smaller proportion in atmosphere as particulate or vapors [4]. They are different sources of heavy metals in agricultural fields: all sources of heavy metals can be divided into five categories as follows [5]:- 1, geochemical sources: in geological terms, heavy metals are included in the group of elements referred to as (trace metals) which together constitute less than $1 \%$ of the rocks in the earth crust; the macro elements $(\mathrm{O}, \mathrm{Si}, \mathrm{Al}, \mathrm{Fe}, \mathrm{Ca}, \mathrm{Na}, \mathrm{K}, \mathrm{Mg}, \mathrm{Ti}, \mathrm{H}, \mathrm{p}$ and $\mathrm{S}$ ) comprise $99 \%$ of the earth crust. The natural enrichment of metals in the soils may still give rise to harmful effect to living organisms. 2 , agriculture material: agriculture constitutes one of the most important non-point sources of metals pollutants; the main sources are (impurities in fertilizers, pesticides, disscants, wood preservative, wastes from intensive pig and poultry productions, composts and manures, sewage sludge. 3, metallurgical industries. 4, waste disposal. 5, other sources in manufacture and disposal (include: batteries, pigments and paints, catalysts, polymer stabilizers, additive in fuels and lubricants).

Metal-bearing solids at contaminated sites can originate from a wide variety of anthropogenic sources in the form of metal mine tailings, disposal of high metal wastes in improperly protected landfills, leaded gasoline and lead-based paints, land application of fertilizer (trace amounts of heavy metals as impurities), animal manures, biosolids (sewage sludge), compost, pesticides, waste water (such as: sanitary sewage, chemical waste water, industrial mining waste water and urban mining mixed sewage). coal combustion residues, petrochemicals, and atmospheric deposition ( airborne sources of metals include stack or duct emissions of air, gas, or vapor streams, and fugitive emissions such as dust from storage areas or waste piles) [6]. 
Soil is of major importance for life since it represents a source of both water and nutrients for plants and soil-living microorganisms and animals. Quantitatively, micronutrients are negligible constituents of soils, but the concentrations and availability of these nutrients are still of great importance for plant development and for obtaining high yields in crop production. Soil micronutrients are derived from minerals in the geological parent material, where the composition of the bedrock, the texture and the degree of weathering of the mineral soil have a large influence on the amount of micronutrients stored and released.

The heavy metals essentially become contaminants in the soil environments because (i) their rates of generation via man-made cycles are more rapid relative to natural ones, (ii) they become transferred from mines to random environmental locations where higher potentials of direct exposure occur, (iii) the concentrations of the metals in discarded products are relatively high compared to those in the receiving environment, and (iv) the chemical form (species) in which a metal is found in the receiving environmental system may render it more bioavailable [7].

The concentration of heavy metals in soil is influenced by various physicochemical characteristics of soil such as $\mathrm{pH}$, particle size distribution, organic matter, cation exchange capacity, and moisture content of the soil [8]. The method of binding heavy metals, and hence their bioavailability, depends on several soil properties, which include [9]: Organic matter content, granulometric composition, occurrence and form of cations, $\mathrm{pH}$ value, content of macro and micronutrients, oxidation-reduction potential, activity of microorganisms, bioavailability for plants. Soils having granulometric composition characteristic for clay, silt and dust, and those with a high content of organic matter, have a high sorption capacity and a strong ability to bind metallic elements [10]. Soil $\mathrm{pH}$ is a major determinant of metal mobility in the soil, as $\mathrm{pH}$ decreases the solubility of the metal cation increases due to desorption from soil minerals such as carbonates, metal oxides and hydroxides [11]. The increase of hydrogen ion concentration affects the mobilization intensity of heavy metals. In highly acidic soils, the mobility of metallic elements is much higher than in soils with neutral and alkaline reaction [12].

The cement industry is an energy intensive and significant contributor to climate change. The major environment health and safety issues associated with cement production are emissions to air and energy use. Cement manufacturing requires huge amount of non renewable resources like raw material and fossil fuels. It is estimated that $5-6 \%$ of all carbon dioxide greenhouse gases generated by human activities originates from cement production [13]. Raw material and Energy consumption result in emissions to air which include dust and gases. The exhaust gases from a cement kiln contains are nitrogen oxides (NOx), carbon dioxide, water, oxygen and small quantities of dust, chlorides, fluorides, sulfur dioxide, carbon monoxide, and still smaller quantities of organic compounds and heavy metals [14]. Toxic metals and organic compounds are released when industrial waste is burnt in cement kiln. Other sources of dust emissions include the clinker cooler, crushers, grinders, and materials-handling equipment.

Air pollutants such as heavy metals, generated in the process of crushing limestone, bagging, and transportation of cement are carried by wind and deposited on soil, plants and water bodies [15].The dust deposition from cement factory influenced by wind velocity, particle size, and stack fumes. Among the metals especially recognized in environmental studies on emission from cement plants to have toxic effect on soil are arsenic, cadmium, lead, mercury, thallium, aluminum, beryllium, chromium, copper, manganese, nickel and zinc [16]. Arpita and Mitko (2011)[17] reported that top soils near a cement factory are enriched in $\mathrm{Pb}, \mathrm{Zn}, \mathrm{Cr}, \mathrm{Cd}, \mathrm{V}$, $\mathrm{Pb}$ and $\mathrm{Hg}$ which are released into the air from the cement kilns. The results of elementary chemical analysis, expressed in weight percent of oxides, conducted by (Young-Chull and Jae-Min, 2004) [18] showed that the raw material dust of the first grinding process primarily consisted of $\mathrm{CaO}(41.77 \%), \mathrm{SiO}_{2}(11.72 \%), \mathrm{Al}_{2} \mathrm{O}_{3}(3.45 \%)$, and $\mathrm{Fe}_{2} \mathrm{O}_{3}(1.47 \%)$. (Samuel and Aynalem, 2012) also reported that two soil depths $(0-5 \mathrm{~cm} \& 5-15 \mathrm{~cm})$ are similarly categorized as moderately to heavily contaminated on the level of heavy metals.

Due to the increasing trends of heavy metals contamination in the environment and their negative impact on plants and other organisms, it is important to mitigate the toxicity of heavy metals from the environment which has become a burning issue. Determining the physicochemical properties of soil and their trace metal content is therefore important to monitor environmental pollution related to cement industries. Therefore, the study was undertaken with a general objective of investigating the level of heavy metals in soil and barley crop around Mugher cement factory, central Ethiopia. The specific objectives of the study were:

- To investigate the available and total concentration of heavy metals ( $\mathrm{Fe}, \mathrm{Mn}, \mathrm{Cu}, \mathrm{Zn}, \mathrm{Cd}, \mathrm{As}$, $\mathrm{Cr}$ and $\mathrm{Pb}$ ) in soil

- To determine the level of heavy metals (Fe, $\mathrm{Mn}, \mathrm{Cu}, \mathrm{Zn}, \mathrm{Cd}, \mathrm{As}, \mathrm{Cr}$ and $\mathrm{Pb}$ ) in barley crop

- To evaluate major physico-chemical properties of soil (pH, EC, Moisture, Bulk density, Total nitrogen, P, K, Oc, S and Cation Exchange Capacity)

\section{Materials and Methods}


Series AAS), Spectro photometer (Janway 6300), pH meter (HI 9017 microprocesser HANNA), conductivity meter (Janway 4310), Muffle furnace, analytical balance, pistel and mortar and crop grinding machine .

All reagent chemical used were analytical grades; distilled water was used for dilution and preparation of reagents. Traceable to NIST stock solutions, $1000 \mathrm{ppm}$, were used to prepare a serious of heavy metal standards.

Description of sampling site

The study area is Mugher, around Mugher cement factory, which is located $90 \mathrm{~km}$ North West of Addis Ababa, Ethiopia. It lays at an elevation of 2,450 m above sea level. The average wind speed at a height of $10 \mathrm{~m}$ above ground level was $1.0 \mathrm{~km} / \mathrm{h}$ between October- November and $0.72 \mathrm{Km} / \mathrm{h}$ between April- May [19]. The mother plant of the factory has three production lines with production capacity of 5000 tons of clinker per day. The farmers around in this area commonly harvests cereal crops such as Wheat, Barley, Teff and Sorghum once in a year from October to November.

\section{Sample collections and preparation}

Soil sample collection and preparation

The soil samples were collected at the time of harvesting cereal crop at $20 \mathrm{~cm}$ depth. Random sampling techniques were followed to collect soil samples from experimental fields of: $0-500 \mathrm{~m}, 500-1500 \mathrm{~m}$ and $\approx 4000$ $\mathrm{m}$ from the factories regards to the cement dust concentration gradients and the availability of selected crop. With auger, about $1 \mathrm{~kg}$ a total of 36 soil samples, were taken from the experimental fields. Every sample was coded properly, the sample bags marked with codes using permanent marker. All the sample information regarding sampling locations, source, date of collection and allotted codes were recorded in the observation register and brought to Holetta Agricultural Research laboratory for preparation and analysis. The collected soil samples were transferred to plastic trays and break up the large clods to speed up drying. The sample then airdried, crushed with mortar and pestle and passed through a 10-mesh (2-mm opening) stainless steel sieve and preserved for laboratory analysis [20,21].

\section{Barley crop sample collections and preparation}

Before sowing at the time of harvesting, about $100 \mathrm{~g}$ a total of 22 barley crop samples, were collected from the spots of soil samples taken. Paper bags were used to store the collected sample and brought to Holetta Agricultural Research laboratory for preparation and analysis. The collected crop samples were threshed, placed in clean acid washed porcelain crucibles and oven dried at $70{ }^{\circ} \mathrm{C}$ for 24 hour in drying oven. The dried samples were then grounded in to a fine powder and kept in desiccators before analysis begun [22].

\section{Sample digestions and extractions}

Dry ashing, barley samples

$1.0 \mathrm{~g}$ of grounded barley samples were weighed in crucible, placed in muffle furnace and ash to $550{ }^{\circ} \mathrm{C}$ for 2 hours. The ash dissolved with $1 \mathrm{~mL}$ concentrated hydrochloric acid, filtered in $100 \mathrm{~mL}$ volumetric flask and marked with distilled water [22]. Dilution applied when the sample reading was not in acceptable working standard range.

\section{Extraction of soil samples, available heavy metals using $\mathrm{NH}_{4} \mathrm{HCO}_{3}-\mathrm{DTPA}$}

Reagent preparation of extraction reagent,

$0.005 \mathrm{M}$ diethylene triamine pentaacetic acid (DTPA) solution was prepared by adding $9.85 \mathrm{~g}$ DTPA to $4500 \mathrm{~mL}$ water in a $5000 \mathrm{~mL}$ volumetric flask. It was shaked constantly for $5 \mathrm{~h}$ to dissolve the DTPA, and brought to 5000 $\mathrm{mL}$ with distilled water. This solution is stable with regard to $\mathrm{pH}$. To $900 \mathrm{ml}$ of the $0.005 \mathrm{M}$ DTPA solution, $79.06 \mathrm{~g}$ ammonium bicarbonate $\left(\mathrm{NH}_{4} \mathrm{HCO}_{3}\right)$ gradually added and stirred gently with a rod to facilitate dissolution and prevent effervescence when bicarbonate is added. The solution was diluted to $1000 \mathrm{~mL}$ with the $0.005 \mathrm{M}$ DTPA solution, mixed gently with a rod and the $\mathrm{pH}$ adjusted to 7.6 with drop wise additions of $2 \mathrm{M}$ hydrochloric acid $(\mathrm{HCl})$ and slow agitation with a rod.

\section{Extraction Procedure}

$10 \mathrm{~g}$ soil sample were weighed in a $125 \mathrm{~mL}$ conical flask and $20 \mathrm{~mL}$ extraction reagent $(0.005 \mathrm{M}$ diethylene triamine pentaacetic acid solution) was added and shake on reciprocal shaker for $15 \mathrm{~min}$ at 180 cycles/min with flasks kept open. The extracts were filtered immediately through Whatman 42 filter paper [23].

\section{$\mathrm{HNO}_{3}-\mathrm{HClO}_{4}$ soil total heavy metals digestion}

Following the procedure recommended by the AOAC (1990), one gram of sample was placed in a $250 \mathrm{ml}$ digestion tube and $10 \mathrm{ml}$ of concentrated $\mathrm{HNO}_{3}$ was added. The mixture was boiled gently for 45 min to oxidize all easily oxidizable matter. After cooling, $5 \mathrm{ml}$ of $70 \% \mathrm{HClO}_{4}$ was added and the mixture was boiled gently until dense white fumes appeared. After cooling, $20 \mathrm{ml}$ of distilled water was added and the mixture was boiled further to release any fumes. The solution was cooled, further filtered through Whatman No. 42 filter paper and $<0.45 \mu \mathrm{m}$ Millipore filter paper and transferred quantitatively to a $25 \mathrm{ml}$ volumetric flask by adding distilled water.

\section{Preparation of working standard solution, calibration and instrument condition}

Working standard solutions of copper $(\mathrm{Cu})$, iron $(\mathrm{Fe})$, zinc $(\mathrm{Zn})$, manganese $(\mathrm{Mn})$, chromium $(\mathrm{Cr})$, arsenic (As), lead $(\mathrm{Pb})$ and cadmium $(\mathrm{Cd})$ were prepared from the stock standard solutions $(1000 \mathrm{ppm})$. The instrument was 
calibrated with five series of calibration standard solutions and measurements of elements were done by using the atomic absorption spectrophotometer (AAS) (Model: Agilent, 200 Series AA).

Table 1. Instrument operating conditions and detection limit of AAS

\begin{tabular}{|l|l|l|l|c|c|}
\hline $\begin{array}{l}\text { Heavy } \\
\text { metals }\end{array}$ & $\begin{array}{l}\text { Wavelength } \\
(\mathrm{nm})\end{array}$ & $\begin{array}{l}\text { Slit width } \\
(\mathrm{nm})\end{array}$ & Flame type & $\begin{array}{c}\text { Required detection } \\
\text { limit } \\
(\mathrm{mg} / \mathrm{l})\end{array}$ & $\begin{array}{c}\text { Instrument detection } \\
\text { limit } \\
(\mathrm{mg} / \mathrm{l})\end{array}$ \\
\hline $\mathrm{Fe}$ & 372.0 & 0.2 & Air-acetylene & 0.50 & 0.0060 \\
\hline $\mathrm{Mn}$ & 403.1 & 0.2 & Air-acetylene & 0.20 & 0.0020 \\
\hline $\mathrm{Zn}$ & 213.9 & 1.0 & Air-acetylene & 0.10 & 0.0010 \\
\hline $\mathrm{Cu}$ & 324.8 & 0.5 & Air-acetylene & 0.50 & 0.0030 \\
\hline $\mathrm{Pb}$ & 283.3 & 0.5 & Air-acetylene & 1.00 & 0.0010 \\
\hline $\mathrm{Cr}$ & 429.0 & 0.5 & Air-acetylene & 0.25 & 0.0060 \\
\hline $\mathrm{Cd}$ & 228.8 & 0.5 & Air-acetylene & 0.20 & 0.0020 \\
\hline $\mathrm{As}$ & 197.2 & 1.0 & N 2 O- acetylene & 1.00 & 0.3000 \\
\hline
\end{tabular}

Data quality control

Appropriate quality assurance procedures and precautions were carried out to ensure reliability of the results. De-ionized water was used to the reagent preparation and sample dilution throughout the study. The analytical balances, drying oven, muffle furnace and glass wares used in the laboratory were calibrated and certified by the calibration body.

For each physico-chemical parameters of soil samples: triplicate analyses were conducted together with the internal laboratory (Holetta Agricultural Research) control sample to verify the precision and accuracy of the results. The internal quality control sample is the sample used as a control by the laboratory in each soil physicochemical parameters. It has known method validation summary: - precision (reproducibility and repeatability), measurement uncertainty and known Mean $\pm \mathrm{SD}$ values. Outliers between triplicates measurement of sample analysis were checked by verifying the \% RSD (percent relative standard deviation).

During analysis with Atomic Absorption Spectrometer; freshly prepared working standard serious, method blanks and internal control samples were used. Instrumental sensitivity was checked during calibration with absorbance reading of prepared working standard. The instrument adjusted:-Each sample, reagent bank and standard results obtained by averaged three points $(<5 \%$ between duplicates $)$ of a single measurements; the correlation coefficient values of working standards is $>0.9998$. Re-calibration and re-slop were done in the intervals of 20 sample measures (referred by the instrument default value, i.e. 50). Duplicates and spikes used during each batch of analysis and the summery of the result are indicated in Tables $5 \& 6$.

Data analysis

Statistical analyses were carried out using SPSS software, version 20. One way ANOVA, descriptive statics, was used for comparing the mean concentration physico-chemical properties of soil and level of heavy metals in barley with in experimental treatments (distances from the factory). Significance difference among treatments $(0-500 \mathrm{~m}, 500-1500 \mathrm{~m}$ and $4000 \mathrm{~m}$ from the factory) indicated for each parameter at $\mathrm{p}<0.05$ and the results were reported as mean \pm standard deviation.

\section{Results}

Effect of cement dust pollution on the level of soil heavy metals content

Table 2: Extractable heavy metals (AB-DTPA) and Total heavy metals $\left(\mathrm{HNO}_{3}-\mathrm{HClO}_{4}\right)$

\begin{tabular}{|c|c|c|c|c|c|c|c|}
\hline $\begin{array}{l}\text { Type of } \\
\text { HMs } \\
\end{array}$ & Treatments & $\mathrm{Fe}$ & Mn & \begin{tabular}{l} 
Zn \\
\hdashline$-(\mathbf{p p m})$ \\
-
\end{tabular} & $\mathbf{C u}$ & $\mathrm{Cr}$ & $\mathbf{P b}$ \\
\hline $\begin{array}{l}\text { Extractable } \\
\text { (AB-DTPA) }\end{array}$ & $\begin{array}{l}0-500 \mathrm{~m} \\
500-1500 \mathrm{~m} \\
\approx 4000 \mathrm{~m}\end{array}$ & $\begin{array}{l}194.33 \pm 9.87 c \\
335.33 \pm 20.79 b \\
683.67 \pm 10.41 a\end{array}$ & $\begin{array}{c}1.25 \pm 0.16 c \\
8.12 \pm 1.13 b \\
11.26 \pm 0.99 a\end{array}$ & $\begin{array}{r}9.37 \pm 0.84 c \\
22.44 \pm 4.27 b \\
42.05 \pm 2.13 a\end{array}$ & $\begin{array}{l}0.90 \pm 0.18 c \\
2.19 \pm 0.22 b \\
2.68 \pm 0.02 a\end{array}$ & $\begin{array}{c}1.40 \pm 0.17 a \\
0.19 \pm 0.00 b \\
0.22 \pm 0.03 b\end{array}$ & $\begin{array}{c}0.73 \pm 0.09 a \\
0.48 \pm 0.04 b \\
0.20 \pm 0.03 c\end{array}$ \\
\hline $\begin{array}{l}\text { Total heavy metals } \\
\left(\mathrm{HNO}_{3}-\mathrm{HClO}_{4}\right)\end{array}$ & $\begin{array}{l}0-500 \mathrm{~m} \\
500-1500 \mathrm{~m} \\
\approx 4000 \mathrm{~m}\end{array}$ & $\begin{array}{c}58.61 \pm 4.53 a \\
36.33 \pm 5.13 b \\
29.89 \pm 1.20 c\end{array}$ & $\begin{array}{l}1255.92 \pm 37.62 a \\
734.32 \pm 57.06 c \\
1101.18 \pm 33.10 b\end{array}$ & $\begin{array}{r}105.66 \pm 8.11 b \\
127.54 \pm 7.99 a \\
70.58 \pm 2.11 c\end{array}$ & $\begin{array}{l}76.28 \pm 4.29 a \\
57.06 \pm 2.69 b \\
52.02 \pm 0.89 b\end{array}$ & $\begin{array}{l}15.55 \pm 2.63 a \\
10.28 \pm 1.53 b \\
8.23 \pm 0.90 c a\end{array}$ & $\begin{array}{r}11.63 \pm 1.48 a \\
5.81 \pm 0.57 b \\
4.61 \pm 0.00 c\end{array}$ \\
\hline Permissible limit & & - & 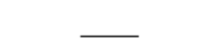 & $150-300$ & $50-140$ & 100 & $50-300$ \\
\hline
\end{tabular}

(ECC 1986)

Mugher site, around Mugher cement factory. The mean $\pm S D$ value, experimental treatments $(0-500 \mathrm{~m}, 500-1500 \mathrm{~m}$ and $\approx 4000 \mathrm{~m})$. Except to $\mathrm{Fe}$ in total heavy metals that expressed in percent (\%); $\mathrm{Cu}, \mathrm{Mn}, \mathrm{Zn}, \mathrm{Pb}$ and $\mathrm{Cr}$ level are expressed in $\mathrm{ppm}(\mathrm{mg} / \mathrm{kg})$. ECC, limits described by European community commission for the level of total heavy metals. The significance difference indicated as ' $a$ ', ' $b$ ' and ' $c$ '. 
Effect of cement dust pollution on major soils physico-chemical properties

Table 3: $\mathrm{pH}, \mathrm{EC}, \mathrm{BD}$ and Texture

\begin{tabular}{|c|c|c|c|c|}
\hline \multirow{2}{*}{\multicolumn{2}{|c|}{ Parameters }} & \multicolumn{3}{|c|}{ Experimental treatments (distance from the factory) } \\
\hline & & $0-500 \mathrm{~m}$ & $500-1500 \mathrm{~m}$ & $\approx 4000 \mathrm{~m}$ \\
\hline \multicolumn{2}{|l|}{ pH } & $8.09 \pm 0.14 \mathrm{a}$ & $6.93 \pm 0.21 b$ & $5.86 \pm 0.10 \mathrm{c}$ \\
\hline \multicolumn{2}{|c|}{$\mathrm{EC}(\boldsymbol{\mu S} / \mathrm{cm})$} & $133.08 \pm 18.29 \mathrm{a}$ & $98.33 \pm 41.65 \mathrm{ab}$ & $68.00 \pm 17.20 \mathrm{~b}$ \\
\hline \multicolumn{2}{|c|}{ BD $\left(\mathrm{g} / \mathrm{cm}^{3}\right)$} & $1.280 \pm 0.08 \mathrm{ab}$ & $1.305 \pm 0.07 \mathrm{a}$ & $1.188 \pm 0.04 \mathrm{~b}$ \\
\hline \multicolumn{2}{|c|}{ Moisture (\%) } & $10.47 \pm 2.76 \mathrm{a}$ & $9.20 \pm 2.24 \mathrm{a}$ & $9.13 \pm 1.10 \mathrm{a}$ \\
\hline \multirow[t]{3}{*}{ Texture } & (\%) clay & $46.25 \pm 16.89 \mathrm{a}$ & $33.13 \pm 7.47 \mathrm{a}$ & $50.00 \pm 6.07 \mathrm{a}$ \\
\hline & (\%) silt & $20.00 \pm 2.04 \mathrm{a}$ & $26.88 \pm 7.18 \mathrm{a}$ & $25.00 \pm 0.70 \mathrm{a}$ \\
\hline & $(\%)$ sand & $33.75 \pm 15.07 \mathrm{a}$ & $40.00 \pm 5.40 \mathrm{a}$ & $25.00 \pm 2.00 \mathrm{a}$ \\
\hline \multicolumn{2}{|c|}{$\mathrm{CEC}\left(\mathrm{cmol}_{\mathrm{c}} \mathrm{kg}^{1}{ }^{1}\right)$} & $40.30 \pm 8.71 \mathrm{a}$ & $39.69 \pm 2.31 \mathrm{ab}$ & $31.50 \pm 1.00 \mathrm{~b}$ \\
\hline \multicolumn{2}{|c|}{ Corg. (g/kg) } & $9.07 \pm 3.74 \mathrm{c}$ & $18.66 \pm 4.03 \mathrm{~b}$ & $35.52 \pm 0.00 \mathrm{a}$ \\
\hline \multicolumn{2}{|c|}{ Ntot. (g/kg) } & $0.64 \pm 0.32 \mathrm{c}$ & $1.46 \pm 0.28 b$ & $2.74 \pm 0.11 \mathrm{a}$ \\
\hline \multicolumn{2}{|c|}{$\mathrm{S}_{-\mathrm{SO}^{-2}}{ }_{4}\left(\mathrm{mg} \mathrm{kg}^{-1}\right)$} & $4.08 \pm 0.99 \mathrm{c}$ & $5.86 \pm 1.81 \mathrm{~b}$ & $6.83 \pm 0.09 \mathrm{a}$ \\
\hline \multicolumn{2}{|c|}{$\mathrm{P}\left(\mathrm{mg} \mathrm{kg}^{-1}\right)$} & $25.25 \pm 17.36 \mathrm{~b}$ & $51.15 \pm 14.17 \mathrm{a}$ & $57.21 \pm 3.24 \mathrm{a}$ \\
\hline \multicolumn{2}{|c|}{$\mathbf{k}\left(\mathbf{c m o l ~ k g} \mathbf{~ g}^{-1}\right)$} & $0.69 \pm 0.10 \mathrm{a}$ & $0.68 \pm 0.04 \mathrm{a}$ & $0.76 \pm 0.00 \mathrm{a}$ \\
\hline
\end{tabular}

$\mu \pm S D$ of $p H$, Electric conductivity, Bulk density, Texture, Cat-ion Exchange Capacity,

Organic carbon, Total nitrogen, $\mathrm{S}-\mathrm{SO}^{-2}{ }_{4}$, Phosphorus and Potassium

THE LEVEL OF HEAVY METALS IN BARLEY

Table 4: The average concentration of Heavy Metals in barley sample

\begin{tabular}{|c|c|c|c|c|}
\hline \multirow{2}{*}{$\begin{array}{c}\text { Parameters } \\
\begin{array}{c}\text { Heavy metals } \\
\text { (ppm) }\end{array}\end{array}$} & \multicolumn{3}{|c|}{ Experimental treatments (distance from the factory) } & \multirow{2}{*}{$\begin{array}{c}\text { FAO/WHO } \\
\text { limit }\end{array}$} \\
\hline & $0-500 \mathrm{~m}$ & $500-1500 \mathrm{~m}$ & $\approx 4000 \mathrm{~m}$ & \\
\hline $\mathbf{F e}$ & $199.09 \pm 5.88 \mathrm{c}$ & $289.90 \pm 11.53 \mathrm{a}$ & $256.40 \pm 3.00 \mathrm{~b}$ & 425.5 \\
\hline Mn & $34.74 \pm 2.06 \mathrm{a}$ & $18.66 \pm 0.14 \mathrm{~b}$ & $20.78 \pm 1.80 \mathrm{~b}$ & 500 \\
\hline Zn & $26.16 \pm 2.19 \mathrm{a}$ & $20.68 \pm 2.09 \mathrm{~b}$ & $20.01 \pm 0.98 \mathrm{~b}$ & 99.4 \\
\hline $\mathbf{C u}$ & $3.83 \pm 0.29 b$ & $4.28 \pm 0.19 \mathrm{a}$ & $3.09 \pm 0.08 \mathrm{c}$ & 73.3 \\
\hline $\mathrm{Cr}$ & $0.77 \pm 0.08 \mathrm{a}$ & $0.83 \pm 0.05 \mathrm{a}$ & $0.65 \pm 0.01 b$ & 2.3 \\
\hline $\mathbf{P b}$ & $0.12 \pm 0.01 \mathrm{a}$ & $0.12 \pm 0.02 \mathrm{a}$ & $0.09 \pm 0.01 \mathrm{a}$ & 0.3 \\
\hline
\end{tabular}

The level of heavy metals express in ppm (mg kg-1) dry weight. The significant differences at $\mathrm{p}<0.05$ are indicated by ' $\mathrm{a}$ ', 'b' and 'c'. 


\section{QUALITY CONTROLS}

Table 5: Quality control values of soil chemical properties

\begin{tabular}{|c|c|c|c|c|c|c|c|c|c|}
\hline \multicolumn{10}{|c|}{ Duplicates } \\
\hline No. & $\mathrm{pH}$ & $\begin{array}{l}\mathrm{EC} \\
(\mu \mathrm{S} / \mathrm{cm})\end{array}$ & $\begin{array}{l}\text { CEC } \\
(\mathrm{cmol} / \mathrm{kg})\end{array}$ & $\begin{array}{l}\mathrm{O}_{\mathrm{C}} \\
(\%)\end{array}$ & \multicolumn{2}{|l|}{$\begin{array}{l}\mathrm{TN} \\
(\%)\end{array}$} & $\begin{array}{l}\mathrm{P} \\
(\mathrm{mg} / \mathrm{kg})\end{array}$ & $\begin{array}{l}\mathrm{K} \\
(\mathrm{cmol} / \mathrm{kg})\end{array}$ & $\begin{array}{l}\mathrm{S} \\
(\mathrm{mg} / \mathrm{kg})\end{array}$ \\
\hline \multirow[b]{2}{*}{1} & 5.93 & 76.4 & 32.40 & 1.838 & \multicolumn{2}{|c|}{0.196} & 7.411 & 0.58 & 8.39 \\
\hline & 6.02 & 74.2 & 31.30 & 1.861 & \multicolumn{2}{|c|}{0.189} & 7.690 & 0.60 & 8.10 \\
\hline \multirow[b]{2}{*}{2} & 7.32 & 90.4 & 35.40 & 2.506 & \multicolumn{2}{|c|}{0.213} & 9.978 & 0.62 & 10.48 \\
\hline & 7.47 & 93.1 & 33.90 & 2.540 & \multicolumn{2}{|c|}{0.220} & 9.706 & 0.61 & 9.99 \\
\hline \multirow[b]{2}{*}{3} & 7.97 & 131.2 & 31.48 & 1.297 & \multicolumn{2}{|c|}{0.099} & 24.360 & 0.66 & 5.81 \\
\hline & 8.01 & 134.2 & 33.00 & 1.251 & \multicolumn{2}{|c|}{0.102} & 25.190 & 0.63 & 5.81 \\
\hline \multirow[b]{2}{*}{4} & 7.94 & 171.6 & 24.90 & 1.074 & \multicolumn{2}{|c|}{0.099} & 34.560 & 1.00 & 5.81 \\
\hline & 7.89 & 175.3 & 24.38 & 1.112 & & 03 & 35.780 & 0.96 & 5.67 \\
\hline & 7.90 & 97.0 & 37.44 & 1.532 & & 21 & 41.595 & 0.62 & 5.86 \\
\hline 5 & 7.82 & 99.2 & 36.10 & 1.582 & & 24 & 42.614 & 0.59 & 5.72 \\
\hline & 7.14 & 105.0 & 36.12 & 2.828 & & 19 & 40.243 & 0.78 & 8.38 \\
\hline 6 & 7.23 & 108.0 & 35.11 & 2.871 & & 11 & 40.991 & 0.76 & 8.38 \\
\hline & 7.01 & 77.4 & 37.46 & 1.793 & & 68 & 59.672 & 0.68 & 3.77 \\
\hline 7 & 7.14 & 74.6 & 36.99 & 1.712 & & 64 & 61.841 & 0.67 & 3.63 \\
\hline & 7.02 & 123.0 & 34.28 & 3.521 & & 75 & 122.430 & 0.84 & 1.89 \\
\hline 8 & 7.14 & 117.2 & 35.32 & 3.574 & & 71 & 118.012 & 0.81 & 1.80 \\
\hline $\begin{array}{l}\text { RPD } \\
\text { (range) }\end{array}$ & $0.50-2.03$ & 2.13-4.83 & 1.26-4.71 & 1.24-3.48 & 1.2 & 3.64 & 1.84-3.7 & $1.48-4.65$ & $0.00-4.87$ \\
\hline & & & & Spikes & & & & & \\
\hline & & & 1.847 & 0.168 & & 11.1 & & 0.58 & \\
\hline 1 & & & $1.896^{*}$ & $0.161^{*}$ & & 11.7 & & $0.59 *$ & \\
\hline & & & 1.423 & 0.102 & & 32.9 & & 0.76 & \\
\hline 2 & & & $1.397^{*}$ & $0.099^{*}$ & & 31.8 & & $0.74 *$ & \\
\hline & & & 1.010 & 0.087 & & 13.8 & & 0.65 & \\
\hline 3 & & & $1.021^{*}$ & $0.084^{*}$ & & 13.9 & & $0.62 *$ & \\
\hline & & & 3.552 & 0.274 & & 57.2 & & 0.76 & \\
\hline 4 & & & $3.641^{*}$ & $0.284^{*}$ & & 54.7 & & $0.77 *$ & \\
\hline $\begin{array}{l}\% \\
\text { recovery }\end{array}$ & & & 97.42-101.86 & 96.48-1 & 4.35 & 95.5 & -104.47 & 98.31-104.84 & \\
\hline
\end{tabular}

\section{'*' refers spikes values}

The result showed in Table 5 showed the quality control values of soil sample analysis. Duplicates and spikes were used in each batch of chemical analysis. Relative percent deviation and recovery values are reported for duplicates and spikes respectively. In general, Relative percent deviation (RPD) ranges between 0.00 to 4.87 and \% recovery from 95.52 to 104.84 from duplicates and spikes respectively. 
Table 6: quality control values for heavy metals in soil and barley samples

\begin{tabular}{|c|c|c|c|c|c|c|}
\hline & \multicolumn{6}{|c|}{ Duplicates( for soil samples) } \\
\hline \multirow[b]{2}{*}{ No. } & \multicolumn{6}{|c|}{$\mathrm{mg} / \mathrm{kg}$} \\
\hline & $\mathbf{F e}$ & Mn & $\mathbf{Z n}$ & $\mathbf{C u}$ & $\mathrm{Cr}$ & $\mathbf{P b}$ \\
\hline \multirow[b]{2}{*}{1} & 421 & 37.25 & 10.90 & 4.01 & 0.182 & 0.512 \\
\hline & 416 & 35.92 & 10.40 & 3.87 & 0.179 & 0.492 \\
\hline \multirow[b]{2}{*}{2} & 368 & 16.70 & 10.36 & 3.90 & 2.892 & 1.204 \\
\hline & 374 & 15.93 & 10.12 & 3.75 & 2.761 & 1.224 \\
\hline \multirow[b]{2}{*}{3} & 359 & 9.23 & 25.80 & 2.08 & 2.304 & 0.525 \\
\hline & 342 & 8.97 & 24.90 & 2.10 & 2.208 & 0.500 \\
\hline \multirow[b]{2}{*}{4} & 188 & 1.22 & 10.80 & 1.23 & 1.981 & 1.431 \\
\hline & 197 & 1.26 & 10.30 & 1.19 & 2.011 & 1.501 \\
\hline $\begin{array}{l}\text { RPD } \\
\text { (range) }\end{array}$ & $1.19-4.85$ & 2.86-4.72 & 2.34-4.74 & $0.96-3.92$ & $1.50-4.63$ & $1.64-4.65$ \\
\hline \multicolumn{7}{|c|}{ Duplicates( for barley samples) } \\
\hline \multicolumn{7}{|c|}{$\mathrm{mg} / \mathrm{kg}$} \\
\hline & $\mathbf{F e}$ & Mn & $\mathbf{Z n}$ & $\mathrm{Cu}$ & $\mathbf{P b}$ & $\mathrm{Cr}$ \\
\hline \multirow[b]{2}{*}{5} & 185.045 & 38.060 & 21.637 & 3.998 & 0.803 & 0.080 \\
\hline & 180.240 & 39.146 & 22.107 & 3.988 & 0.804 & 0.081 \\
\hline \multirow[b]{2}{*}{6} & 273.050 & 18.583 & 19.228 & 4.400 & 0.772 & 0.108 \\
\hline & 279.104 & 18.412 & 19.023 & 4.541 & 0.781 & 0.11 \\
\hline \multirow[b]{2}{*}{7} & 245.740 & 46.334 & 22.083 & 5.598 & 1.201 & 0.204 \\
\hline & 254.81 & 45.395 & 21.997 & 5.675 & 1.222 & 0.209 \\
\hline \multirow[b]{2}{*}{8} & 281.694 & 18.079 & 18.156 & 4.099 & 0.820 & 0.123 \\
\hline & 290.031 & 18.103 & 18.391 & 4.162 & 0.831 & 0.125 \\
\hline $\begin{array}{l}\text { RPD } \\
\text { (range) }\end{array}$ & 2.19-3.62 & $0.13-0.28$ & $0.39-2.15$ & $0.24-3.15$ & $0.16-1.70$ & $1.24-2.31$ \\
\hline
\end{tabular}

Note: RPD , relative percent deviation between duplicates samples.

The result indicated in Table 6 showed that the quality control values of heavy metals in soil and barley. The RPD in soils ranges from 0.96 to 4.85 and from 0.13 to 3.62 in barley sample. The quality control results (Table 5 and Table 6) between duplicates and spikes in over all have shown that $<5 \%$, implies that it has in acceptable range [24].

\section{DISCUSSION}

\section{Extractable heavy metals}

Ammonium bicarbonate-diethylenetriaminepentaacetic acid extracting solution was used to extract available forms of heavy metals from the soil sample. It is widely accepted that determining the total content of heavy metals in a soil is neither sufficient to understand their relative mobility and ecological availability as contaminants nor particularly useful as a tool to estimate potential risks. At $\mathrm{p}<0.05$, the descriptive statics shows that there is significance difference among experimental treatments $(0-500 \mathrm{~m}, 500-1500 \mathrm{~m}$ and $\approx 4000 \mathrm{~m}$ away from the factories). Except to chromium and lead one way ANOVA revealed that higher and significantly different level of extractable heavy metals obtained go away from the factory. It is well known that metals solubility in soils mainly depends on soil $\mathrm{pH}$, organic $\mathrm{C}, \mathrm{CEC}$, and clay contents $[25,26]$. Therefore the variation of the extractable heavy metals dominantly related with the $\mathrm{pH}$ variation of the study area that have showed in Table 5 (moderately acidic $>$ neutral $>$ moderately alkaline) comes from liming effects by the cement dust. Limits described by MacLean [27] on $\mathrm{Cr}$, Pb and $\mathrm{Cd}$ level extracted with AB-DTPA are $8 \mu \mathrm{g} / \mathrm{g}, 13 \mu \mathrm{g} / \mathrm{g}$ and $0.31 \mu \mathrm{g} / \mathrm{g}$ respectively. This shows that extractable chromium, lead and cadmium level in the study area are below the critical permissible levels.

\section{Total heavy metals}

The di-acid wet oxidation carried out by employing oxidizing acids, $\mathrm{HNO}_{3}-\mathrm{HClO}_{4}$. The control field $(\approx 4000 \mathrm{~m}$ from the factory) significantly different and lower in contents than cement polluted areas of the experimental fields $(0-500 \mathrm{~m}$ and $500-1500 \mathrm{~m})$. The levels of Fe consistently decline towards go away from the factory. Young-Chull [28] pointed out that the results of elementary chemical analysis on the raw material dust of the 
first grinding process consisted of $1.47 \% \mathrm{Fe}_{2} \mathrm{O}_{3}$. This is therefore enhances the level of iron in the study area with respect to the control field $(\approx 4000 \mathrm{~m}$ from the factory). The following table shows the pattern of heavy metals pollutions of cement dust polluted areas with respect to the control site.

Table 7: Geo-accumulation Index

\begin{tabular}{|c|c|c|}
\hline \multirow{2}{*}{ Heavy metals } & \multicolumn{2}{|c|}{ Barley experimental Plot } \\
\cline { 2 - 3 } & \multicolumn{2}{|c|}{$\operatorname{Igeo}^{2} \log _{2}\left[{ }^{\mathrm{C}} \mathrm{n} / 1.5 \mathrm{~B}_{\mathrm{n}}\right]$} \\
\hline $\mathrm{Fe}$ & $0-500 \mathrm{~m}$ & $\begin{array}{c}500-1500 \mathrm{~m} \\
/ \approx 4000 \mathrm{~m}\end{array}$ \\
\hline $\mathrm{Mn}$ & -0.19 & -0.40 \\
\hline $\mathrm{Zn}$ & -0.42 & -0.65 \\
\hline $\mathrm{Cu}$ & -0.30 & -0.22 \\
\hline $\mathrm{Cr}$ & -0.31 & -0.47 \\
\hline $\mathrm{Pb}$ & -0.20 & -0.38 \\
\hline
\end{tabular}

Mugher site, around Mugher cement factory. The pollution indices, the pattern of metal contamination in the area. The value calculated for each heavy metal is with respect to the control (the value obtained $\approx 4000 \mathrm{~m}$ ) i.e. treatment $1(0-500 \mathrm{~m}) /$ control \& treatment $2(500-1500 \mathrm{~m}) /$ control.

Table 7 shows the pattern of heavy metals pollutions of cement dust polluted areas with respect to unpolluted. Igeo is calculated through the following equation as applied by [29-31]. $\operatorname{Igeo}=\log _{2} 10\left[\frac{\mathrm{Cn}}{1.5 \mathrm{Bn}}\right]$, where $\mathrm{Cn}$ represents the measured total concentration of metals in the soil $(\mathrm{mg} / \mathrm{kg})$; and $\mathrm{Bn}$ represents the geochemical background values of the metals $(\mathrm{mg} / \mathrm{kg})$. For the analysis of the geochemical background values of heavy metals $(\mathrm{Bn})$, uncontaminated surface soils were used where both anthropogenic and industrial activities are minimal and can represent geological background with reference to heavy metals. The constant 1.5 is introduced to minimize the effect of possible variations in the background values which may be attributed to lithological variations in the soils [32]. The constant 1.5 also helps to analyze natural fluctuation between the content of a given substance in environment and very small anthropogenic influences.

Table 8: Igeo classes with respect to soil quality

\begin{tabular}{|c|c|l|}
\hline Class & Value & \multicolumn{1}{|c|}{ Soil quality } \\
\hline 0 & Igeo $<0$ & Practically unpolluted \\
\hline 1 & $0<$ Igeo $<1$ & unpolluted to moderately polluted \\
\hline 2 & $1<$ Igeo $<2$ & Moderately polluted \\
\hline 3 & $2<$ Igeo $<3$ & Moderately to strongly polluted \\
\hline 4 & $3<$ Igeo $<4$ & strongly polluted \\
\hline 5 & $4<$ Igeo $<5$ & strongly to very strongly polluted \\
\hline 6 & $5<$ Igeo $<6$ & Strongly polluted \\
\hline
\end{tabular}

Table 8 refers that the seven ranges of contamination values have been determined to assess the degree of trace metals' pollution [33]. According to Galkus and Boszke [33, 34], the value indicated Igeo $<0$ that the soil quality is practically unpolluted.

Therefore the pollution index and the permissible limit on soil quality have proved that the soil in the study area is unpolluted with heavy metals.

\section{pH, EC, BD and Texture}

The mean \pm SD of $\mathrm{pH}, \mathrm{EC}, \mathrm{BD}$ and Texture are summarized in Table 3. Soil $\mathrm{pH}$ is a crucial soil indicator defined as the negative $\log$ of the hydrogen ion activity. The $\mathrm{pH}$ range normally found in soils varies from 3 to 9 . The significance of $\mathrm{pH}$ lies in its influence on availability of soil nutrients, solubility of toxic nutrient elements in the soil, physical breakdown of root cells, and CEC in soils whose colloids (clay/humus) are pH-dependent and biological activity. Most crops grow best when the soil $\mathrm{pH}$ is between 6.0 and 8.2 . From the table, $\mathrm{pH}$ value are significantly differ in all treatments in the order of treatment one $(0-500 \mathrm{~m}$, moderately alkaline $)>$ treatment two $(500-1500 \mathrm{~m}$, neutral $)>$ treatment three $(\approx 4000 \mathrm{~m}$, slightly acidic $)$.

Particle size distribution (soil texture) is an important parameter in soil classification and has implications for soil water, aeration, and nutrient availability to plants. Laboratory procedure [35] normally estimate percentage of sand $(0.05-2.0 \mathrm{~mm})$, silt $(0.002-0.05 \mathrm{~mm})$, and clay $(<0.002 \mathrm{~mm})$ fractions in soils. Soil texture triangle shows that the samples in the study area are clay to clay loam soil.

Soil bulk density (BD) is ratio of the mass (oven-dry weight) of the soil to the bulk volume which includes the volume of both solids and pore space at specified soil water content (usually the moisture content at sampling). Soil moisture influences crop growth not only by affecting nutrient availability, but also nutrient transformations and soil biological behavior.

Soil salinity refers to the concentration of soluble inorganic salts in the soil. It reflects the extent to which 
the soil is suitable for growing crops. Values of 0 to $200 \mu \mathrm{S} / \mathrm{cm}$ are safe for all crops; yields of very sensitive crops are affected between 200 to $400 \mu \mathrm{S} / \mathrm{cm}$; many crops are affected between 400 and $800 \mu \mathrm{S} / \mathrm{cm}$; while only tolerant crops grow reasonably well above that level. I.e. Barley (Hordeum vulgare) upper tolerable limit is 1800 $\mu \mathrm{S} / \mathrm{cm}[36]$. In the Table 3 the results have shown that the soil salinity (electric conductivity) is safe and suitable to grow barley as well as for all cereals crops.

Total nitrogen, Organic carbon, phosphorus and Sulfur

Total nitrogen analysis measures $\mathrm{N}$ in all organic and inorganic forms. The organic fraction constitutes the majority of total $\mathrm{N}$ in soils (usually $>95 \%$ ). It is composed mostly of plant and microbial remains, in variable composition. The inorganic phase of soil $\mathrm{N}$ is composed of ammonium $\left(\mathrm{NH}_{4}\right)$, nitrate $\left(\mathrm{NO}_{3}\right)$, and-very little though-nitrite $\left(\mathrm{NO}_{2}\right)$ forms. Environmental (temperature and moisture) and agronomic management (fertilization, cropping, etc.) factors influence its dynamic relationship with the organic fractions and also within the inorganic forms [36]. Only 1 to 4 percent of this total $\mathrm{N}$ becomes plant-available (converts via microbial activity from organic form to inorganic form) during a growing season [37]. Soil organic matter (OM) has a major influence on soil aggregation, nutrient reserve and its availability, moisture retention, and biological activity. As soil test interpretation guide [37], soil OM increases so does CEC, soil total $\mathrm{N}$ content, and other soil properties such as water-holding capacity and microbiological activity increases parallel. The contents of total nitrogen and organic carbon of treatment $1(0-500 \mathrm{~m})$ is significantly differ and lower than the respective treatments. Soil test interpretation guide [37] refers that the organic carbon and total nitrogen in soil are collarets each other, Table 3 also support the correlation.

The level of phosphorus in treatment 1 , near to the factory, is a medium content soil category and significantly differ from the respective treatments. The content of phosphorus increases and significantly different when the $\mathrm{pH}$ changes from moderately acidic ( $\mathrm{pH}: 5.86)$ to neutral ( $\mathrm{pH}: 7.02)$. This can be due to fixing of available $\mathrm{P}$ content in acidic soil with cations like Al.

Sulfur (S) exists in soil and soil solution mainly as the sulfate $\left(\mathrm{SO}_{4}-\mathrm{S}\right)$ and Plants absorb sulfur in this form. Along with $\mathrm{N}$ and $\mathrm{P}$, potassium $(\mathrm{K})$ is also of vital importance in crop production. It has categorized that medium content of potassium.

\section{Heavy metals in Barley crop}

Arsenic (As) and Cadmium (Cd) were not detected in any of the cereal samples analyzed in the study area. The levels of heavy metals determined in the analyzed cereal samples were found to be below the permissible limit set by FAO/WHO [38].The heavy metal transfer factor of each heavy metals from soils to barley crop is calculated using the formula [39]:- $T F=\frac{M P}{M S}$; Where: TF - transfer factor, Mp - metal content in plant $\left(\mathrm{mg} \mathrm{kg}^{-1}\right)$, $\mathrm{Ms}-$ metal content in soil $\left(\mathrm{mg} \mathrm{kg}^{-1}\right)$. By using the data of Table 4 for Mp and Table 2 for Ms, the result for all heavy metals analyzed are below one. If the ratios $>1$, the plants have accumulated elements, the ratios around 1 indicate that the plants are not influenced by the elements, and ratios $<1$ show that plants exclude the elements from the uptake [40]. Therefore the selected cereal crop (barley) in the study area are safe for consumptions.

\section{Conclusion}

Consuming the cereals contaminated with heavy metals has different detrimental effects on human health; therefore, monitoring contamination of heavy metals will allow for avoiding unnecessary exposures. The result of this study has revealed that the various concentrations of the heavy metals $\mathrm{Cu}, \mathrm{Fe}, \mathrm{Zn}, \mathrm{Mn}, \mathrm{Cr}, \mathrm{As}, \mathrm{Pb}$ and $\mathrm{Cd}$ in Barley collected from Mugher site around Mugher cement factory of the Oromia Regional State, central Ethiopia. The concentrations of heavy metals determined were $\mathrm{Fe}, \mathrm{Mn}, \mathrm{Zn}, \mathrm{Cu}, \mathrm{Cr}, \mathrm{Pb}$; As and $\mathrm{Cd}$ were not detected in any of the cereal crops. Generally, the levels of heavy metals obtained in barley are within the acceptable ranges and calculated values of transfer factor shows the crop not influenced by heavy metals that uptaked from the dust polluted fields in study area. Therefore this crop harvested from cement dust polluted experimental fields do not pose toxic effect to the health of their consumers, may as well serve as sources of trace metals to the population. Further studies recommend to carried out on the yield of cereal crops grown in the study area.

From soil data-Igeo values were calculated for each heavy metal with respect to control $(\approx 4000 \mathrm{~m}$ far from the factory). The value indicated Igeo $<0$ that the soil quality is practically unpolluted. According to soil interpretation guide, the major nutrient status (i.e. phosphorus, nitrogen, and potassium) are medium to high category. The phosphorus, organic carbon, total nitrogen, potassium and sulfur contents of soil polluted with cement dust are decrease/significantly differ in contents than the control ( $\approx 4000 \mathrm{~m}$ from the factory). In general, the factory should monitor the dust pollution emanates during cement production that changes the physicochemical properties of soil by enhancing the $\mathrm{pH}$ level. Its recommend that carrying out further studies on speciation of heavy metals in soil and yields of cereals crop. 


\section{Conflict of interest}

The author have not declared any conflict of interest.

\section{Acknowledgments}

The author would like to thank the program of agricultural and nutritional research, Ethiopia Institute of Agricultural Research, for financial and providing laboratory facilities.

\section{References}

[1]. Muhammad, Z.I; Muhammad, S. (2001). Periodical effect of cement dust pollution on the growth of some plant species. Turk J. Bot, 25, 19-24

[2]. Princewill, C. Ogbonna; Adanma, N.N. (2011). Metal concentration in soil and plants in abandoned cement factory. Int Conference on Biotechnology and Environment Management IPCBEE, 18, Singapore

[3]. Sposito G and A. L. (1984). "Cycling of metal ions in the soil environment," in Metal Ions in Biological Systems, H. Sigel, Ed., vol.18 of Circulation of Metals in the Environment, pp. 287-332, Marcel Dekker, Inc., New York, NY, USA.

[4]. Mildvan AS. (1970). Metal in enzymes catalysis. In: Boyer DD (ed) The enzymes, vol 11. Academic Press, London, pp 445-536

[5]. Alloway. B. J. and Ayres, D. C. (1993). Chemical Principles of Environmental Pollution. Blackie Academic \& Professional, an imprint of Chapman \& Hall, Wester Cleddens Road, Bishopbriggs, Glasgow

[6]. Basta NT, Ryan JA, and Chaney RL. (2005). "Trace element chemistry in residual-treated soil: key concepts and metal bioavailability," Journal of Environmental Quality, vol. 34, no. 1, pp. 49-63.

[7]. D'Amore JJ, Al-Abed SR, Scheckel KG, and Ryan JA. (2005). "Methods for speciation of metals in soils: a review," Journal of Environmental Quality, 34 (5): 1707-1745.

[8]. Aloysius AP, Rufus SA and John OO (2013a). Evaluation of heavy metals in soils around auto mechanic workshop clusters in Gboko and Makurdi, Central, Nigeria, J Environ Chem Ecotoxicol 5 (11): 298-306.

[9]. Nouri J., Khorasani N., Lorestani B., Karami M., Hassani A.H., Yousefi N (2009). Accumulation of heavy metals in soil and uptake by plant species with phytoremediation potential, Environ. Earth Sci. 59, 315-323.

[10]. Sheoran V., Sheoran A.S., Poonia P (2009). Phytomining: A review, Minerals Engineering 22: 1007-1019.

[11]. Bozkurt, S, Moreno, L, and Neretnieke, I (2002). Long term process in waste deposit. Sci Total Environ 250: 101-121.

[12]. Vamerali, T., Bandiera, M., and Mosca, G (2010). Field crops for phytoremediation of metal- contaminated land. A review, Environ.Chem. Lett. 8: 1-17.

[13]. Potgieter Johannes H (2012). An Overview of Cement production: How "green" and sustainable is the industry.

[14]. Marlowe Ian and Mansfield David. (2002).Toward a Sustainable Cement Industry Substudy 10: Environment, Health \& Safety Performance Improvement, December, an Independent Study Commissioned by WBCSD

[15]. Kabir, G. and Madugu, A.I. (2010). Assessment of environmental impact on air quality by cement industry and mitigating measures: A case study. Environ. Monit. Assess., 160: 91-99.

[16]. Addo, M.A; Darko, E.O. (2012). Evaluation of heavy metals contamination of soil and vegetation in the vicinity of a cement factory in the Volta region, Ghana. Int. J. Science and Technology, $2,1$.

[17]. Arpita, M; Mitko, V. (2011). Heavy metals in soils around the cement factory in Rockfort, Kingston, Jamaica. Int. J. Geosciences, 2, 48-54.

[18].Young-Chull and Jae-Min. (2004). Physical chemical and electrical analysis of dust generated from cement plants for dust removal with an electrostatic precipitation, 21(1): 182-186

[19]. Feleke B. (2014). Energy audits in Mugher cement enterprise, Adis Ababa, Ethiopia.

[20]. Reeuwijk, LP van (2002). Technical paper in procedures in soil analysis. $6^{\text {th }}$ edition.

[21]. Virgina Cooperative Extension program. (2011). Soil testing laboratory procedures: 452-881

[22]. Chapman H.D., and Pratt. (1961). Method of analysis for soils, plants and water.

[23]. Benton jones, j. jr. (1999). Soil analysis hand book of reference methods 139-145

[24]. Scott Tucker, Derek Walker (2015). Quality Control Definitions and Analysis Procedures

[25]. Hough, R.L., S.D. Young and N.M.G. Crout (2003). Modeling of Cd, Cu, Ni, Pb and Zn uptake by winter wheat and forage maize, from a sewage disposal form. Soil Use Manage.19:19-27.

[26]. Walker, D.J., R. Clemente, A. Roig and M.P. Bernal. (2003). The effects of soil amendments on heavy metal bioavailability in two contaminated Mediterranean soils. Environ. Pollut. 22(2):303-312.

[27]. MacLean, K.S., A.R. Robinson and H.M. MacConnell (1987). The effect of sewage-sludge on the heavy metal content of soils and plant tissue. Commun.Soil Sci. Plant Anal. 18:1303-1316

[28].Young-Chull and Jae-Min. (2004). Physical chemical and electrical analysis of dust generated from cement plants for dust removal with an electrostatic precipitation, 21(1): 182186. 
[29]. Krupadam, R.J; Smita, P; Wate; S.R. (2006). Geochemical fractionation of heavy metals in sediments of the tapi estuary. Geochemical Journal, 40, 513-522.

[30]. Emmanuel OF and Edward OO. (2010). Evaluation of the status of heavy metal pollution of soil and plant. American-Eurasian Journal of Scientific Research, 5(4), 241-248.

[31]. Abdulrasoul, M; Al-Omran; Salem, E; El-Maghraby; Mahmoud, E.A; Nadeem, A; El-Eter, M; Salem M.I; Al-Qahtani. (2011) Impact of cement dust on some soil properties around the cement factory in Al-Hasa Oasis, Saudi arabia. American-Eurasian, J. Agric. \& Environ. Sci, 11(6), 840-846.

[32]. Sampson, A.M; Francis, O.G. (2011) Contamination assessment of heavy metals in road dust from selected roads in Accra, Ghana. Research Journal of Environmental and Earth Sciences, 3(5), 473-480.

[33]. Galkus A., joksas K., stakeniene R., lagunaviciene L. (2012). Heavy metal contamination of harbour bottom sediments, Pol. J. Environ. Stud. 21 (6), 1585.

[34]. Boszke L., sobczynski T., kowalski A (2004). Distribution of Mercury and Other Heavy Metals in Bottom Sediments of the Middle Odra river (Germany/Poland). Polish Journal of Environmental Studies, 13 (5), 495.

[35]. Bouyoucos, G. H. (1951) reclamation of the hydrometer for making mechanical analysis of soil. Agro. Jour. 43: 434-438.

[36]. George Estefan, R.S. and John Ryan (2013). Method of soil, plant and water analysis, $3^{\text {rd }}$ edition.

[37]. Donald A. Horneck, Dan M. Sullivan, Jim S. Owen, and John M. Hart (2011). Soil Test Interpretation Guide

[38]. FAO/WHO; Codex alimentaruis Commission (2001). Food additives and contaminants, Joint FAO/WHO Food Standard Program

[39]. Oyedele D, Gasu MB, Awotoye OO (2008). Changes in soil properties and plant uptake of heavy metals on selected municipal solid waste dump sites in Ile-Ife, Nigeria, J. Environ. Sci. Technol 3(5): 107-115

[40]. Olowoyo, J.O., van Heerden, E., Fischer, J.L. and Baker, C. (2010). Trace metals in soil and leaves of Jacaranda mimosi folia in Tshwane area, South Africa. Atmospheric Environment 44: 1826-1830. 